\title{
Effects of Chronic Administration of Efavirenz on the Chromatophilic Substance of the Intracranial Auditory Relay Centres of Adult Wistar Rats
}

\author{
Efectos de la Administración Crónica de Efavirenz sobre la Sustancia Cromatofílica \\ de los Centros de Relevo Auditivos Intracraneales de Ratas Wistar Adultas
}

Adjene, J. O. \& Igbigbi, P. S.

ADJENE, J. O. \& IGBIGBI, P. S. Effects of chronic administration of efavirenz on the chromatophilic substance of the intracranial auditory relay centres of adult wistar rats. Int. J. Morphol., 30(3):993-998, 2012.

SUMMARY: The effects of chronic administration of efavirenz commonly used as part of highly active antiretroviral therapy (HAART) for the treatment of Human Immunodeficiency Virus (HIV) type-1 therapy on the chromatophilic substance of the intracranial auditory relay centre namely the inferior colliculus and medial geniculate body of adult wistar rats were carefully studied. The rats of both sexes $(n=20)$, with an average weight of $200 \mathrm{~g}$ were randomly assigned into treatment $(n=10)$ and control $(n=10)$ groups. The rats in the treatment group received $600 \mathrm{mg} / 70 \mathrm{~kg}$ body weight of efavirenz dissolved in distilled water daily for 30 days through the orogastric tube. The control group received equal volume of distilled water daily for 30 days through the same route. The rats were fed with grower's mash obtained from Edo Feeds and Flour Mill Limited, Ewu, Edo state, Nigeria and given water liberally. The rats were sacrificed by cervical dislocation method on the thirty-first day of the experiment. The inferior colliculus and medial geniculate body were carefully dissected out and quickly fixed in $10 \%$ formal saline for histological study. The histological findings indicated that the treated sections of the inferior colliculus and medial geniculate body showed that the chromatophilics substances were less intensely stained as compared to the control. The parenchyme was vacuolated and with evidence of hypertrophy and more spaces between the axonal mesh around the sparsely distributed neurons as compared to the control group. The treated section of the inferior colliculus showed neurons with faintly stained chromatophilics substances in large, medium and small sized neurons while that of the medial geniculate body showed less intense and enlarge chromatophilics substances with some vacuolations. Chronic administration of efavirenz may therefore have an adverse effect on the chromatophilics substances of the inferior colliculus and medial geniculate body of adult wistar rats. It is recommended that further studies aimed at corroborating these observations be carried out.

KEY WORDS: Efavirenz; Chromatophilic substance; Inferior colliculus; Medial Geniculate body; Wistar rats.

\section{INTRODUCTION}

Efavirenz is an antiretroviral drug that belongs to the class of drugs called non-nucleoside reverse transcriptase inhibitor (NNRTI) used as part of highly active antiretroviral therapy (HAART) for the treatment of human immunodeficiency virus (HIV) type-1 (AHFS, 2007). Efavirenz has been found to be effective in many combination regimes for the treatment of HIV infection, both in previously untreated and in treated individuals. It has been combined successfully with nucleoside consisting of lamivudine or emtricitabine plus abacavir, didanosine, stavidine, tenofovir or zidovudine to achieve virologic suppression in a high percentage of recipients (Staszewski et al., 1999; Gulick et al., 2006). Most antiviral agents do not efficiently penetrate the blood brain barrier (BBB) or are actively transported out of the central nervous system (Schranger \& D'Souza, 1998). Even after antiviral treatment that successfully controls virus in the treatment compartments, the central nervous system may suffer continuing damage induced by HIV infection (Fox et al., 2000). Efavirenz may be taken once a day without regards to meal and it can penetrate the central nervous system and spinal fluids (AIDS INFONET, 2007; Puzantian, 2002)

Some adverse effect in the central nervous system has been commonly associated with efavirenz (Ruiz et al., 1999). The most common central nervous system effects 
include confusion, insomnia, abnormal vivid dreams, dizziness and headache. Efavirenz has emerged as cornerstone of highly active antiretroviral therapy (HAART) regimens. The side effect profile of the drug is generally regarded as satisfactory. However, there are conflicting study results in the medical literature as well as conflicting studies from patients and physicians regarding the neuropsychiatric problems associated with efavirenz (Baker, 2006). Lipodystrophy, moderate or severe pain, abnormal vision, arthralgia. asthenia, dyspnea, gynecomastia, myalgia, myopathy and tinnitus have been reported concerning efavirenz (AHFS).

The inferior colliculus and medial geniculate body constitutes the intracranial auditory relay centres. The inferior colliculus is the obligatory midbrain synaptic target of the ascending auditory pathway, in which the contralateral ear is represented primarily (Fall, 1999). Inferior colliculus is essential for normal hearing and for the startle reflex it receives its ascending input mainly from the contralateral cochlear nucleus and the superior olive and sends axons to the medial geniculate body (Fall). The medial geniculate body is the target of ascending projection from the inferior colliculus and descending input from the auditory cortex this is the obligatory synaptic target in the thalamus for hearing (Fall). It contains interleaved and overlapping tonotopic and aural bands, the most beautiful structure in the brain (Fall). The cerebral cortex strongly affects the medial geniculate body through descending projections. These projections were thought to consist primarily of small areas with slow conduction velocities (Winer et al., 1996). It has been demonstrated that neurons of auditory cortex showed great physiological plasticity when rats were exposed to specific stimuli coupled with concurrent stimulation of a forebrain subcortical structure in the nucleus basalis. Changes include massive expansion of frequency-specific representation (Winer et al., 1999). Cortical structures such as the medial and lateral geniculate bodies, inferior and superior colliculi have higher glucose utilization than other structures (Siesjo, 1978). There is a correlation between functional activity and metabolic rate such as in the visual and auditory system (Siesjo). Since efavirenz crosses the blood brain barrier, it is relevant to investigate its histochemical effect on the inferior colliculi and medial geniculate body. It is probable that the adverse effects of efavirenz on hearing such as tinnitus may be due to direct effect of efavirenz on the inferior colliculi and medial geniculate body.

Chromatophilic substance had been reported to play key roles in cellular metabolism (Adams, 1965). Chromatophilics bodies are nodal points in the endoplasmic reticulum, which permeate the cell body and dendrites. They are absent at the axon and axon hillock (Noback \& Demarest,
1981). It had been reported that chromatophilic body comprises of broadsheet of rough or granular endoplasmic reticulum, free ribosomes and ribosomes in clusters or rosette. These ribosomes had been found in large amounts in the cytoplasm of neurons as cytoplasmic RNA. Under the control of nuclear deoxyribonucleic acid (DNA), cytoplasmic RNA is concerned with protein synthesis. Alterations in chromatophilics substances are characterized by a change of membrane configuration forming lamella bodies such as anulate lamellae as elaborated with electron microscope (Davis \& Robertson, 1991). This present study was to elucidate the effects of chronic administration of efavirenz on the chromatophilic substance of the intracranial auditory relay centre of adult wistar rats.

\section{MATERIAL AND METHOD}

Animals. The School of Basic Medical Sciences, University of Benin grant approval before the work begins. Twenty adult wistar rats of both sexes with average weight of $200 \mathrm{~g}$ were randomly assigned into two groups; control $(n=10)$ and treatment $(n=10)$. The rats were obtained and maintained in the Animal Holding of the Department of Anatomy, School of Basic Medical Sciences, University of Benin, Benin City, Edo State, Nigeria. They were fed with grower's mash obtained from Edo Feeds and Flour Mill Limited, Ewu, Edo State, Nigeria and given water liberally. Efavirenz was obtained from the President Emergency Plan for AIDS Relief (PEPFAR) Unit, University of Benin Teaching Hospital, Benin City, Edo State, Nigeria.

Drug Administration. The rats in the treatment group received the recommended dosage of $600 \mathrm{mg} / 70 \mathrm{~kg}$ body weight of efavirenz dissolved in distilled water for thirty days through orogastric tube administration while the control rats received equal volume of distilled water through the same route and for the same period. The rats were sacrificed by cervical dislocation on the thirty-first day of the experiment. The skulls were opened using bone forceps to expose the brain of the rats and the inferior colliculus and medial geniculate body were quickly dissected out and fixed in $10 \%$ formal saline for chromatophilic substance staining techniques.

Histological study. The tissues were dehydrated in an ascending grade of alcohol (ethanol), cleared in xylene and embedded in paraffin wax. Serial sections of 6 microns thick were obtained using a rotatory microtome. The deparaffused sections were stained routinely for chromatophilic substance using thionin method of Paget \& Eccleston (1960) procedures. The sections were then rinse in distilled water, dehydrated through ascending grades of alcohol, cleared in xylene and 
mounted in DPX for chromatophilic substance observation. The photomicrographs of the desired results were obtained using research photographic microscope in the Department of Anatomy, School of Basic Medical Sciences, University of Benin, Benin City, Edo State, Nigeria.

\section{RESULTS}

The control group of rats showed intensely stained chromatophilics substances in the neurons of the inferior colliculus and medial geniculate body. No vacuolations was observed in the stroma of the inferior colliculus and medial geniculate body of the control wistar rats (Figs. 1A and 2A).

The treated inferior colliculus and medial geniculate body showed that the chromatophilics substances of the neurons were less intensely stained as compared to the constant intense staining observed in the neurons of the control rats. Apart from the characteristic vacuolations in the parenchyma, there appeared to be more spaces between the axonal mesh around the sparsely distributed neurons in the
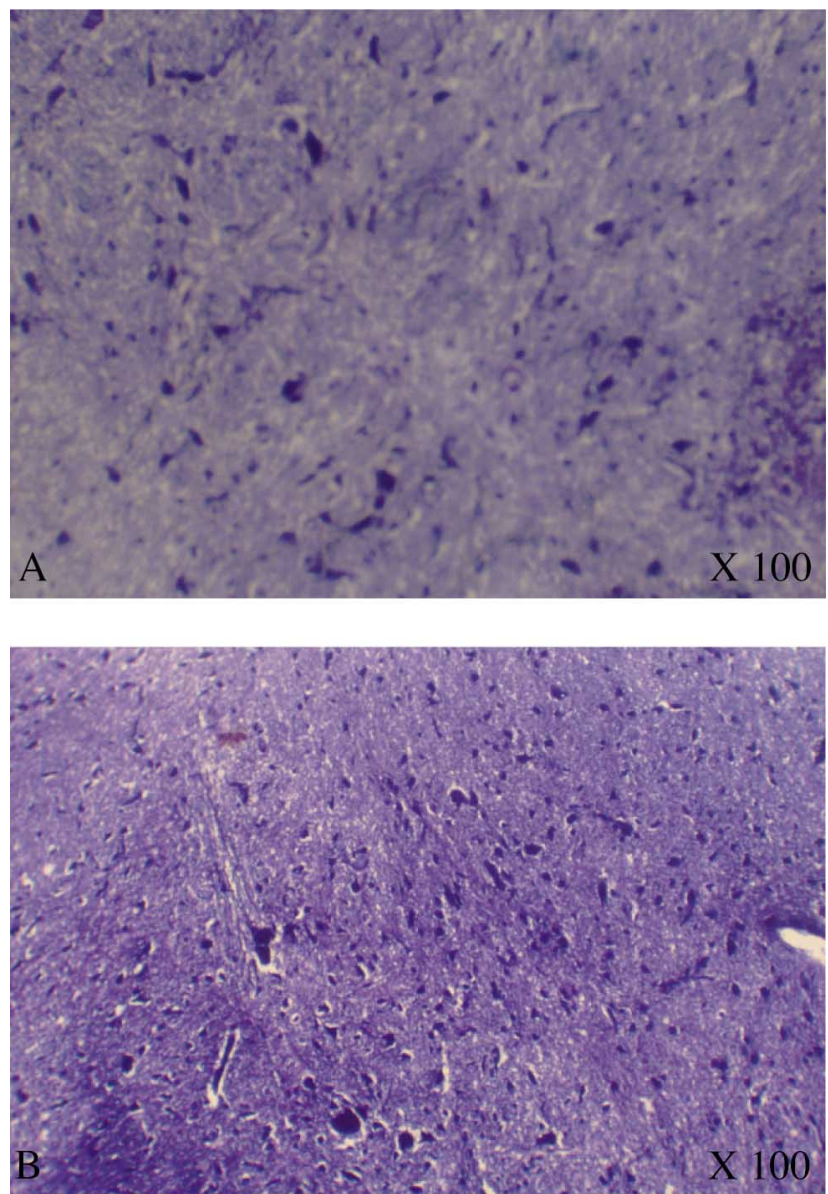

treated rats. This is mostly prominent in the medial geniculate body (Figs. 1B and 2B).

The section of inferior colliculus of the treated rats showed neurons with faintly stained chromatophilics substances in large, medium and small sized neurons. The parenchyme was vacuolated and with evidence of hypertrophy (Figure 1B), while the sections of medial geniculate body of the treated rats showed less intense and enlarge chromatophilics substances in the neurons with some vacuolations (Fig. 2B).

\section{DISCUSSION}

The treated inferior colliculus and medial geniculate body showed that the chromatophilics substances of the neurons were less intensely stained as compared to the constant intense staining observed in the neurons of the control rats. Apart from the characteristic vacuolations in the parenchyma, there appeared to be more spaces between the axonal mesh around the sparsely distributed neurons in the
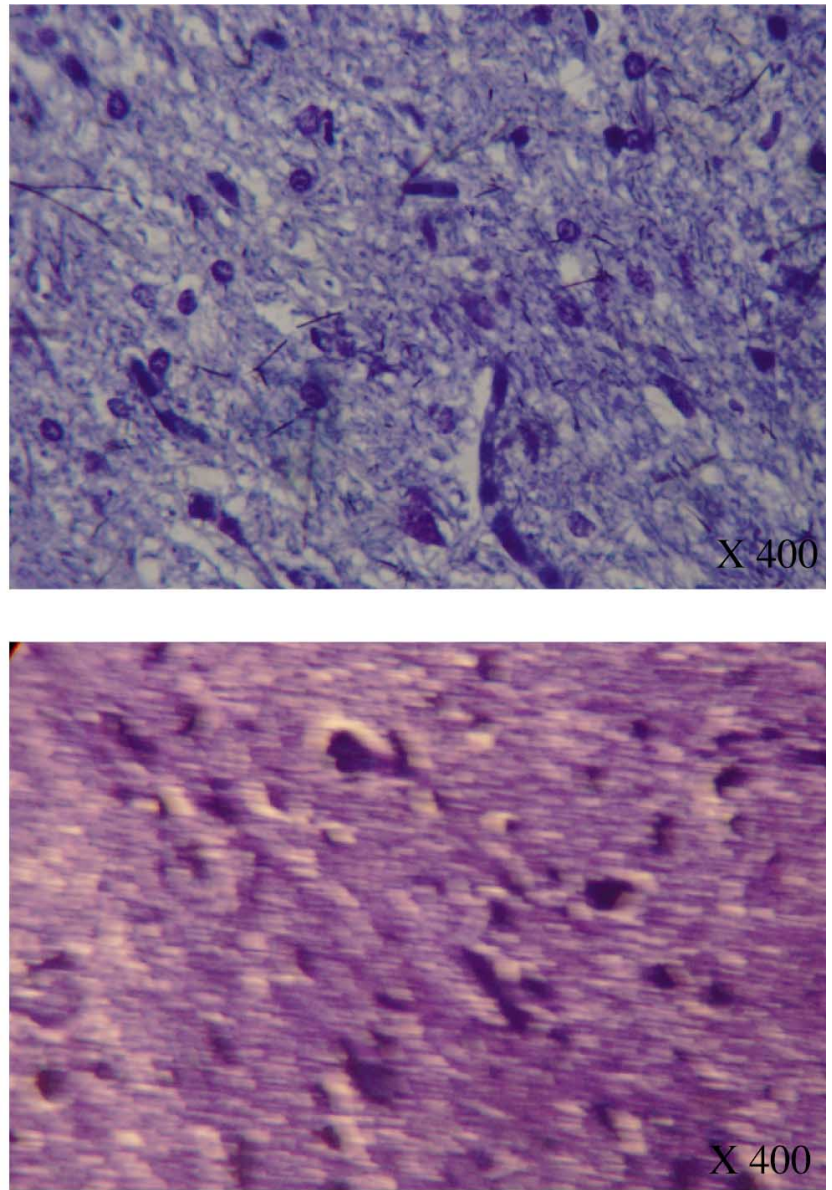

Fig. 1. Chromatophilic substance in the inferior colliculus (IC) (Thionin stain). 

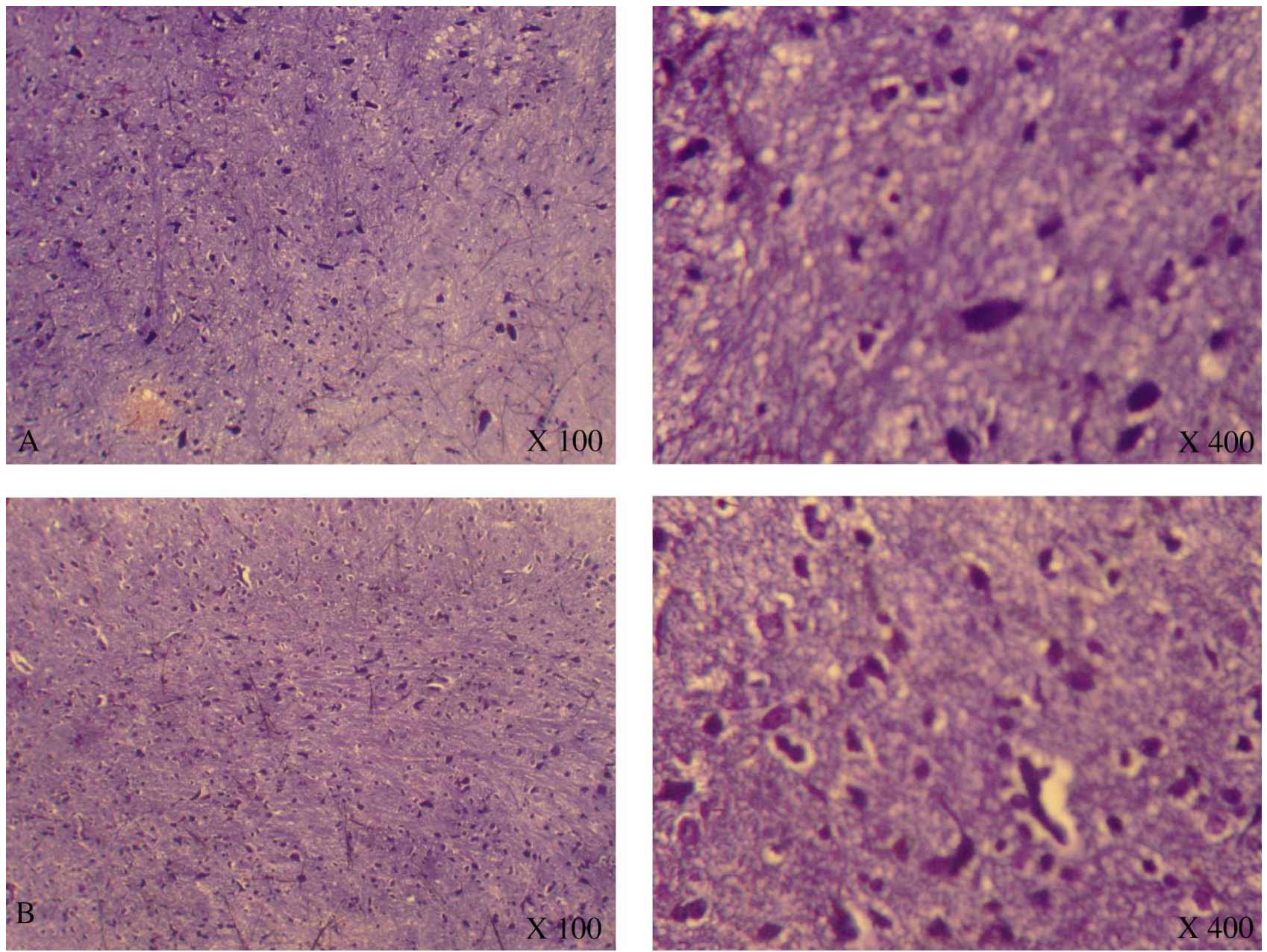

Fig. 2. Chromatophilic substance in the medial geniculate body (MGB) (Thionin stain).

treated rats. This is mostly prominent in the medial geniculate body. The section of inferior colliculus of the treated rats showed neurons with faintly stained chromatophilics substances in large, medium and small sized neurons. The parenchyme was vacuolated and with evidence of hypertrophy, while the sections of medial geniculate body of the treated rats showed less intense and enlarge chromatophilics substances in the neurons with some vacuolations.

Chromatophilics substances had been reported to play key roles in cellular metabolism (Adams). Its depletion in efavirenz treated rats could be of health hazard especially at neuronal level. Under the light microscope, chromatophilics substances range in appearance from rhomboid blocks in large neurons to particulate materials in the cell bodies of smaller neurons. Chromatophilic bodies are nodal points in the endoplasmic reticulum, which permeate the cell body and dendrites. They are absent at the axon and axon hillock (Noback \& Demarest).
Hence their absence in neurons could negatively affect their functions. It had been reported that chromatophilic body comprises of broadsheet of rough or granular endoplasmic reticulum, free ribosomes and ribosomes in clusters or rosette. These ribosomes had been found in large amounts in the cytoplasm of neurons as cytoplasmic RNA. Under the control of nuclear deoxyribonucleic acid (DNA), cytoplasmic RNA is concerned with protein synthesis. The protein synthesized is transported down the axon by axoplasmic flow or transport. If nerve cells require large amounts of protein to maintain their integrity and perform their functional activities (Noback \& Demarest); decreased protein synthesis due to decreased chromatophilic substance leading to decreased neuronal intensity and function as observed in locomotor activities of the treated rats.

Degeneration of chromatophilics substances is usually characterized by disintegration resulting in powdering remains that are confined to the periphery of 
the cell. The cytoplasm appear homogenous, chromatolysis is accompanied by a concomitant decrease in RNA and protein synthesis caused by certain diseased conditions. Other alterations in chromatophilics substances are characterized by a change of membrane configuration forming lamella bodies such as anulate lamellae as elaborated with electron microscope (Davis \& Robertson). In support of our observations, chromatophilics substances have been reported to be altered by chemicals, toxins, certain drugs and oxygen-lack causing loss of function or interference in normal metabolism (Davis \& Robertson). Neuronal degeneration had been reported earlier to cause a decrease in chromatophilics bodies as chromatolysis occurs (Martin et al., 1978). During necrotic cell death, ribosomes are dispersed from the rough endoplasmic reticulum and polyribosomes in disassociate resulting in a number of monomeric ribosomes that are found free in the cytoplasm (Martin et al.). In this study, neuronal degeneration was observed in sections of the inferior colliculus and medial geniculate body in rats treated with efavirenz. The decrease in the staining intensity of the chromatophilic substance in the treatment group may be due to the deleterious effects of efavirenz on the neuronal integrity and its chromatophilics substances with consequent decrease in cellular metabolism. It has been reported that chronic administration of efavirenz resulted in a significant decrease $(\mathrm{P}<0.05)$ in the dry brain weight and a significant increase $(P<0.05)$ in the weight of the dry inferior colliculus of an adult wistar rats as compared to the control group (Adjene \& Arukwe, 2009). Consequently, efavirenz has also been reported to cause some cellular degenerative changes such as sparse cellular population, hypertrophy, some microcystic changes and vacuolations in the stroma of the treated inferior colliculus as compared to the control group in adult wistar rats (Adjene et al., 2010). In this study, efavirenz was observed to cause depletion of chromatophilics substances in the inferior colliculus and medial geniculate body of the treated rats. This observation could underline a possible interference in protein synthesis in the inferior colliculus and medial geniculate body. It is however probable that this consequence of efavirenz on the neuronal metabolism of the inferior colliculus and medial geniculate body may offer possible explanation on the effects of the drug on the nervous system as observed by various workers specially in human and animal models.

In this study, neuronal degeneration was observed in the sections of the inferior colliculus and medial geniculate body in the treated rats with efavirenz. There was a decrease in the staining intensity of the chromatophilic substance, which may be due to the deleterious effects of efavirenz on the neuronal integrity and its chromatophilics substances with consequent decrease in cellular metabolism. Efavirenz was observed to cause depletion of chromatophilics substances in the inferior colliculus and medial geniculate body with a characteristic vacuolations in the parenchyma of the inferior colliculus and medial geniculate body. There appeared to be more spaces between the axonal mesh around the sparsely distributed neurons in the treated rats with that of the medial geniculate bodies more prominent.

ADJENE, J. O. \& IGBIGBI, P. S. Efectos de la administración crónica de efavirenz sobre la sustancia cromatofílica de los centros de relevo auditivos intracraneales de ratas Wistar adultas. Int. J. Morphol., 30(3):993-998, 2012.

RESUMEN: Fueron estudiados los efectos de la administración crónica del efavirenz, comúnmente utilizado como parte del tratamiento antirretroviral de gran actividad para el VIH tipo 1, sobre la sustancia cromatofílica del centro de relevo auditivo intracraneal, el colículo inferior y cuerpo geniculado medial, en ratas Wistar adultas. Ratas de ambos sexos $(\mathrm{n}=20)$, con un peso promedio de $200 \mathrm{~g}$ fueron asignadas aleatoriamente a tratamiento $(\mathrm{n}=10)$ y control $(\mathrm{n}=10)$. Las ratas del grupo tratado recibieron $600 \mathrm{mg} / 70 \mathrm{~kg}$ peso corporal de efavirenz disuelto en agua destilada durante 30 días a través de sonda orogástrica. El grupo de control recibió un volumen igual de agua destilada durante 30 días por la misma vía. Las ratas fueron alimentadas con puré agricultor obtenido de Edo Feeds and Flour Mill Limited, Ewu, estado de Edo, Nigeria y agua ad-libitum. Las ratas se sacrificaron por dislocación cervical el día 31. El colículo inferior y el cuerpo geniculado medial fueron disecados cuidadosamente y se fijaron en solución de formalina salina al $10 \%$. Los hallazgos histológicos indicaron que en las secciones tratadas del colículo inferior y el cuerpo geniculado medial la sustancia cromatofílica fue menos intensamente teñidas en comparación con el control. El parénquima se vacuoló, con evidencia de hipertrofia y más espacios entre la red axonal alrededor de neuronas escasamente distribuidas en comparación con el grupo control. La sección tratada del colículo inferior mostró neuronas con sustancia cromatofílica débilmente teñida en las neuronas de tamaño grande, mediano y pequeño, mientras que las del cuerpo geniculado medial mostraron sustancia cromatofílica menos intensa, con algunas vacuolaciones amplias. La administración crónica de efavirenz puede tener un efecto adverso sobre las sustancias cromatofílica del colículo inferior y del cuerpo geniculado medial de ratas Wistar adultas. Se recomienda realizar estudios adicionales destinadas a corroborar estas observaciones.

PALABRAS CLAVE: Efavirenz; Sustancia cromatofílica; Colículo inferior; Cuerpo geniculado medial; Ratas Wistar. 


\section{REFERENCES}

Adams, C. W. M. Neurochemistry. London, Elsevier Publishing Company, 1965. pp. 253-319.

Adjene, J. O. \& Arukwe, F. I. Effects of chronic administration of efavirenz on the Brain and Inferior colliculus weights of adult wistar rats. Rev. Electron. Biomed./Electron. J. Biomed., 3:3640, 2009.

Adjene, J. O.; Igbigbi, P. S. \& Nwose, E. U. Histological effects of chronic administration of efavirenz on lateral geniculate body of adult Wistar rats. N. Am. J. Med. Sci., 2(1):1-4, 2010.

AIDS INFONET. Efavirenz (Sustiva). Fact. Sheet, 432, 2007.

American Hospital Formulary Service (AHFS). Drug Information, 86-694, 2007.

Baker, R. Central nervous system toxicities and efavirenz, 2006. Available in: www.hivandhepatitis.com

Davis, R. L. \& Robertson, D. M. Textbook of Neuropathology. $2^{\text {nd }}$ ed. London, Williams and Wilkins, 1991. pp.5-7.

Fall, B. Mammalian Neuroanatomy MCB. 163: Mammaalian neuroanatomy, 1999.

Fox, H. S.; Weed, M. R.; Huitron-Resendiz, S.; Baig, J.; Horn, T. F.; Dailey, P. J.; Bischofberger, N. \& Henriksen, S. J. Antiviral treatment normalizes neurophysiological but not movement abnormalities in simian immunodeficiency virus-infected monkeys. J. Clin. Invest., 106(1):37-45, 2000.

Gulick, R. M.; Ribaudo, H. J.; Shikuma, C. M.; Lalama, C.; Schackman, B. R.; Meyer, W. A. 3rd.; Acosta, E. P.; Schouten, J.; Squires, K. E.; Pilcher, C. D.; Murphy, R. L.; Koletar, S. L.; Carlson, M.; Reichman, R. C.; Bastow, B.; Klingman, K. L.; Kuritzkes, D. R. \& AIDS Clinical Trials Group (ACTG) A5095 Study Team. Three- vs four-drug antiretroviral regimens for the initial treatment of HIV-1 infection: a randomized controlled trial. JAMA, 296(7):769-81, 2006.

Martin, L. J.; Al-Abdulla, N. A.; Brambrink, A. M.; Kirsch, J. R.; Sieber, F. E. \& Portera-Cailliau, C. Neurodegeneration in excitotoxicity, global cerebral ischemia, and target deprivation: A perspective on the contributions of apoptosis and necrosis. Brain Res. Bull., 46(4):281-309, 1998.

Noback, R. \& Demarest, A. The human nervous system, basic principles of neurobiology. $3^{\text {rd }}$ ed. Japan, McGraw-Hill International Book Company, 1981. pp.413-5.

Paget, G. E. \& Eccleston, E. Simultaneous specific demonstration of thyrotroph, gonadotroph and acidophil cells in the anterior hypophysis. Stain Technol., 35:119-22, 1960.
Puzantian, T. Central nervous system adverse effects with efavirenz: case report and review. Pharmacotherapy, 22(7):930-3, 2002.

Ruiz, N. M.; Bessen, L. J. \& Manion, D. J. Potential adverse experiences associated with efavirenz (sustiva in adults) for the efavirenz clinical development team. Presented at the 6th Conference on Retrovirus and Opportunistic Infections, Chicago, IL, 1999.

Schrager, L. K. \& D'Souza, M. P. Cellular and anatomical reservoirs of HIV-1 in patients receiving potent antiretroviral combination therapy. JAMA, 280(1):67-71, 1998.

Siesjo, B. K. Utilization of substrates by brain tissues. In: Brain energy Metabolism. New York, John Wiley \& Sons, 1978. pp.101-30.

Staszewski, S.; Miller, V.; Sabin, C.; Schlecht, C.; Gute, P.; Stamm, S.; Leder, T.; Berger, A.; Weidemann, E.; Hill, A. \& Phillips. A. Determinants of sustainable CD4 lymphocyte count increases in response to antiretroviral therapy. AIDS, 13(8):9516, 1999.

Winer, J. A.; Larue, D. T. \& Huang, C. L. Cortical influence on the medial geniculate body. J. Comp. Neurol., 413:181-97, 1999.

Winer, J. A.; Saint Marie, R. L.; Larue, D. T. \& Oliver, D. L. The cerebral cortex strongly affects the medial geniculate body through descending projections. Proc. Nati. Acad. Sci. USA, 93:8005-10, 1996.

\section{Correspondence to: \\ J. O. Adjene}

Department of anatomy and cell biology

Faculty of Basic Medical Sciences

College of Health Sciences

Delta State University

Abraka

Delta State

NIGERIA

Telephone : +2348034084016, +2348053478526

Email: joadjene@yahoo.com, pigbigbi@yahoo.com

Received: 08-11-2011

Accepted: 16-03-2012 